\title{
Uczenie się jako przestrzeń dyskursywnie konstruowana
}

KEYWORDS

learning, discourse, identity

\begin{abstract}
Popow Monika, Uczenie się jako przestrzeń dyskursywnie konstruowana [Learning as a discursive space]. Kultura Społeczeństwo - Edukacja nr 2(12) 2017, Poznań 2017, pp. 273-284, Adam Mickiewicz University Press. ISSN 2300-0422. DOI 10.14746/kse.2017.12.13.
\end{abstract}

The aim of this paper is to present the conception of learning as a discursive space. It presents the existing research in the field of critical discourse theory, cultural processes of learning as well as dialogic theory of learning. Different aspects of discourse of learning are discussed, including learning as a space for identity creation processes. Furthermore the issues of empty signifiers in a discourse of learning as well as cultural aspects of the discourse of learning and its consequences for identity creation processes are raised.

Jak zauważa Alicja Jurgiel-Aleksander, uczenie się jest świadectwem rozwoju człowieka w ciągu całego życia, a także zaangażowania w praktyki społeczne:

myślenie o doświadczeniu należy do świata praktyk społecznych, wymaga pomyślenia o dorosłym już nie tylko jako o kimś, kto jest podmiotem upełnomocnienia, ale o kimś, kto jest promotorem własnej zmiany i otoczenia w procesie własnego uczenia się (...). Przemiany w sferze życia ekonomicznego pod znakiem niestabilności ekonomicznej, ale też nowe możliwości pracy wynikające z rozwoju nowoczesnych technologii skutkują nowymi wzorcami komunikacji, a także społeczną mobilnością i nową kulturą refleksyjnego - a nie opartego na nawykach uczenia się. (Jurgiel-Aleksander, 2012: 41) 
Wprawdzie przytoczony fragment dotyczy uczących się dorosłych, wydaje się jednak, że procesy te rozciągnąć można również na dzieci i młodzież, których zmieniająca się rzeczywistość dotyka w jeszcze większym stopniu. Mówić można zatem ogólnie o podmiotach uczących się, funkcjonujących w coraz bardziej złożonej rzeczywistości społecznej.

To, w jaki sposób i co mówi się o uczeniu się, a także jak konstruowany jest ten proces $\mathrm{w}$ dyskursie publicznym $\mathrm{i} \mathrm{w}$ interakcji, nabiera zatem współcześnie szczególnego znaczenia. Uczenie się jest bowiem integralnym elementem dyskursu publicznego, występującym nie tylko w obrębie dyskursu polityki edukacyjnej, ale, w szerszej perspektywie, w ramach różnych innych dyskursów funkcjonujących w obszarów naszej rzeczywistości społecznej. Wystarczy wspomnieć dyskursy dotyczące rozwoju, transformacji, reform czy rozwoju osobistego, a nawet sportu i fitness. Wzrasta zatem rola uczenia się traktowanego jako naturalna aktywność człowieka niezależnie od wieku, stanowiąca element jego codziennych doświadczeń (Field, 2000).

Jak zauważa Gert Biesta, współcześnie myślenie o edukacji zdominował dyktat uczenia się polegający na konieczności ciągłego dostarczania okazji i możliwości uczenia się klientom rynku edukacyjnego (Biesta, 2010). Obecnie dyskurs uczenia się tworzony jest w bardzo dużym stopniu poprzez język kompetencji i kwalifikacji, a także język rozwoju ekonomicznego, którego uczenie się jest jednym z głównych narzędzi. W tak zwanym społeczeństwie opartym na wiedzy uczenie się to podstawowy instrument rozwoju społecznego. Pozyskanie wiedzy, traktowanej jak towar mogący zostać skomercjalizowany oraz sprzedany, staje się indywidualną sprawą jednostki oraz poszczególnych społeczeństw. W tym kontekście jako pole dyskursywne uczenie się staje się ważnym obszarem konstruowania społecznych znaczeń, a także budowania tożsamości.

W tym miejscu warto przypomnieć, że uczenie się jako proces, a także jako zjawisko kulturowe, ma szczególne znaczenie w kontekście cywilizacyjnym. Wszelkie kolonialne dyskursy, zarówno te historyczne, jak i współczesne, opierają się na opozycji pomiędzy uczącym i uczącym się. Uczący się to ten, kto musi zdobyć wiedzę, aby się ucywilizować. Transmisja wiedzy w kontekście kolonialnym ma charakter hierarchiczny i, pod pozorem cywilizowania, utwierdza nierówne relacje władzy (Young, 1990: 120). W kontekście współczesnych społeczeństw kapitalistycznych mówić można, na przykład, o transmisji wiedzy z zakresu ekonomii i przedsiębiorczości z centrum, jakim jest Globalna Północ, na globalne peryferie. Procesy te Walter Mignolo nazywa geopolityką wiedzy (Mignolo, 2002).

Analizując procesy uczenia się, wychodzę zatem z założenia, że ich społeczne oraz dyskursywne aspekty są obszarem, na którym konstruowane są i odbijają się 
procesy społeczne. Uczenie się traktować będę jako obszar manifestowania się różnorodnych interesów społecznych, kulturowych i politycznych.

Celem niniejszego artykułu jest przedstawienie koncepcji uczenia się rozumianego jako przestrzeń dyskursywna. Artykuł będzie miał charakter przeglądu dotychczasowych badań, służących mi jako podstawa do zrekonstruowania koncepcji uczenia się. Opieram się na pracach badaczy dyskursu, przede wszystkim Jamesa Paula Gee. Inspiracją są również dla mnie teksty Mikhaila Bakhtina, dotyczące dialogicznej teorii uczenia się, a także prace z zakresu krytycznych badań nad kulturowymi aspektami tego procesu, przede wszystkim Bonny Norton.

Artykuł składa się z pięciu części. Najpierw omówię różnorodne aspekty dyskursu uczenia się. Następnie przejdę do uczenia się jako obszaru dyskursywnego konstruowania tożsamości. W kolejnej części przybliżę puste znaczące mogące występować w dyskursie uczenia się, a następnie omówię kulturowe uwarunkowania formowania się dyskursu uczenia się i ich konsekwencje dla procesów formowania tożsamości. Artykuł kończy podsumowanie.

\section{Dyskurs uczenia się - różnorodne aspekty}

Jak zauważają James Paul Gee i Judith Green, w ostatnich dwudziestu latach studia nad dyskursem stały się istotną perspektywą teoretyczną w badaniach nad uczeniem się jako zjawiskiem społecznym (Gee, Green, 1998: 119). Stosowane są one na przykład w badaniach nad społecznym konstruowaniem wiedzy, a także nad związkami pomiędzy dyskursem, praktykami społecznymi i uczeniem się. Perspektywa dyskursywna pozwala również spojrzeć, jak wiedza formuje i sama formowana jest przez działania dyskursywne, praktyki społeczne, różne rodzaje wiedzy, a także różnych aktorów społecznych zaangażowanych w proces produkcji wiedzy (Gee, Green, 1998: 119).

Zanim przejdę jednak do szczegółowych rozważań, chciałabym wprowadzić uściślenie definicyjne pomiędzy dyskursem o uczeniu się, dyskursem uczenia się, a uczeniem się jako przestrzenią dyskursywną, które to jest przedmiotem moich zainteresowań.

Pod pojęciem „dyskurs o uczeniu się” rozumiem wszelkiego rodzaju narracje dotyczące procesu uczenia się w warunkach formalnych i pozaformalnych. Chodzi tutaj zatem o to, co i jak mówi się na ten temat w dyskursie publicznym, a w jego ramach w dyskursie edukacyjnym. Przykładem ilustrującym, co rozumieć można pod tym pojęciem, są różnorodne dyskursy dotyczące praktyk i strategii uczenia się, czy też dyskursy związane z usługami tak zwanego rynku edukacyjnego. Dys- 
kurs o uczeniu się jest również powiązany z dyskursem eksperckim. Bardzo często to właśnie eksperci oraz autorytety edukacyjne, na przykład w ramach dyskursu medialnego, budują narrację dotyczącą definiowania pożądanego i niepożądanego uczenia się, prawidłowego przebiegu oraz pożądanych efektów tego procesu.

Jako dyskurs uczenia się rozumieć możemy natomiast to, co i w jaki sposób mówione jest w sytuacji uczenia się, na przykład w klasie szkolnej. Znaczenie tego pojęcia zbudowane jest tutaj na socjokulturowym spojrzeniu na naturę i funkcje języka, myślenia oraz interakcji społecznych. Tak rozumiany dyskurs uczenia się może być przedmiotem socjokulturowej analizy dyskursu. Interesujące stają się w tym wypadku interakcje pomiędzy różnymi podmiotami tego procesu - najczęściej pomiędzy uczniem i nauczycielem oraz pomiędzy uczniami. Jak ujmuje to Neil Mercer, ludzie w procesie komunikacji konstruują rozumienie dzielonych przez siebie doświadczeń, co też zachodzi w procesie uczenia się. Jest ono procesem dialogicznym, w którym odzwierciedlane są wartości oraz praktyki społeczne i kulturowe zaangażowanych podmiotów, w tym instytucji (Mercer, 2004: 139). Pozwala to postawić pytania o związki pomiędzy językiem, myśleniem oraz co, mówiąc językiem teorii Vygotsky’ego, jest w procesie uczenia się ,intermentalne” i ,intramentalne”, a więc społeczne i psychologiczne. Mercer pisze dalej: „Partnerzy w konwersacji używają języka, aby wspólnie podróżować z przeszłości w przyszłość, wspólnie transformując aktualne rozumienia poszczególnych przedmiot(ów) swojej konwersacji. Aby móc to robić, muszą wybudować kontekstualną podstawę dla swojej rozmowy" (Mercer, 2004: 139). Przywołuje on w tym kontekście prace Gee oraz Green, którzy proces ten nazywają refleksyjnością; do niej również szczegółowo odniosę się w niniejszym artykule. Dyskursem uczenia się w wypadku procesów opisywanych przez Mercera określić można edukacyjne sytuacje komunikacyjne, zachodzące na przykład w klasie szkolnej, rozumiane w kontekście społeczno-kulturowego ich powstawania. W badaniu socjokulturowych aspektów procesów uczenia się koncepcja dyskursu pozwala zobaczyć, w jaki sposób w języku wprowadzane są w tym procesie nowe informacje, a także $\mathrm{w}$ jaki sposób ludzie zaangażowani $\mathrm{w}$ ten proces spotykają się, rozumieją swoje perspektywy oraz produkują wspólne działania (Mercer, 2004: 166).

Podobnie związki pomiędzy uczeniem się i dyskursem rozumieją Per-Olof Wickman i Leif Östman w swojej koncepcji dyskursu klasowego. Interesowało ich, jak znaczenia zmieniają się w dyskursie i jak odnosi się to do procesu uczenia się w klasie szkolnej, a także w jaki sposób uczniowie stają się uczestnikami tego procesu (Wickman, Östman, 2002). Szerzej rzecz ujmując, perspektywa ta pyta, jakie znaczenia nadawane są poszczególnym zjawiskom społecznym w pro- 
cesie uczenia się lub też, jakie znaczenia nadawane są w tym procesie samemu uczeniu się.

Równie interesująca i powiązana z rozumieniem uczenia się jako przestrzeni dyskursywnej jest osadzona w koncepcjach Bakhtina dialogiczna teoria uczenia się. Przyjmując, że jest to konstruowanie albo rekonstruowanie znaczeń społecznej w ramach tymczasowej, społecznie negocjowanej aktywności dyskursywnej (Hicks, 1996: 136), w perspektywie tej zakłada się, że w procesie tym dochodzi do spotkania dwóch albo więcej głosów. Zachodzi zatem nadawanie i rozumienie wypowiedzi, a treść, czyli to, czego uczący się ma się nauczyć, jest tymczasowa, niezdeterminowana niczym oraz warunkowa. Znacząca jest tutaj między innymi stworzona przez Bakhtina koncepcja stratyfikacji języka pod względem zawodowym, społecznym, generacyjnym oraz rodzajowym. Koncepcja dialogiczna stawiać będzie pytanie, jakiego rodzaju język społeczny przyjmowany jest w procesie uczenia się jako język nauki. Nie jest to bowiem wyłącznie terminologia specjalistyczna, ale również konkretny rodzaj języka, służący do opisu jakiegoś rodzaju wizji świata społecznego (Koschmann, 1999).

Przedstawione wyżej aspekty odróżniam od koncepcji uczenia się jako przestrzeni, w ramach której zachodzą procesy dyskursywnego konstruowania tożsamości. Przyjrzę się temu zagadnieniu w kolejnej części mojego artykułu.

\section{Uczenie się jako przestrzeń dyskursywnego konstruowania tożsamości}

Koncepcją, na której szczególnie chciałabym skupić uwagę, jest uczenie się jako przestrzeń dyskursywnego konstruowania tożsamości. Jest ono mocno osadzone w bachtinowskim rozumieniu języka i jego relacji ze światem społecznym. Język w interakcji społecznej tworzy tutaj przestrzeń napięć czy też walki pomiędzy różnymi sposobami mówienia, które odnoszą się do różnych grup społecznych (Bakhtin, 1981; Menard-Warwick, 2005). Jako taka przestrzeń ta formowana jest przez ciągłe zmiany znaczeń, symboli i metafor, odzwierciedlających na przykład zmiany wartości konstytuujących społeczeństwo.

Taka koncepcja uczenia się odwołuje się również do rozumienia dyskursu jako praktyki. James Paul Gee i Judith Green zauważają, że język to coś więcej niż tylko wypowiedzi. Piszą:

język pomaga nam działać. Pozwala angażować się w działania i czynności. Obiecujemy innym coś, otwieramy zebrania, oświadczamy się, kłócimy o politykę i mówimy do Boga (modlimy się). To niektóre spośród niezliczonych rzeczy, jakie, poza dawaniem i uzyskiwaniem informacji, 
robimy z udziałem języka. Język pozwala nam być czymś. Pozwala przybierać różne społecznie znaczące tożsamości. Możemy mówić jako eksperci, lekarze, prawnicy, fani anime, cieśle, albo jako zwyczajni ludzie. Aby przybrać tożsamość w danym miejscu i czasie, musimy wypowiedzieć to autentycznie, a nie tylko sobie pogadać. Jeśli weźmiemy gangi, członkowie ulicznego gangu będą mówić inną mową niż wzorowi uczniowie. Co więcej w różnym czasie i miejscach mogą to być te same osoby (...). (Gee, Green, 1998: 139)

Gee i Green wyróżniają dyskursywnie konstruowane obszary obecne w każdej interakcji:

- budowanie słów - przypisywanie określonych znaczeń dotyczących rzeczywistości, obecnych i nieobecnych, konkretnych i abstrakcyjnych (...);

- budowanie aktywności - przypisywanie określonych znaczeń dotyczących tego, jakie aktywności lub czynności zachodzą, złożone z innych określonych działań (...);

- budowanie tożsamości (osadzonych społecznie) - przypisywanie określonych znaczeń dotyczących tego, jakie tożsamości są odpowiednie w danej interakcji (tekst pisany), wraz z postawami oraz odczuciami, sposobami wiedzenia oraz wierzenia, a także działania i interakcji (...);

- budowanie związków - robienie założeń na temat tego, w jaki sposób przeszłość i przyszłość interakcji połączone są z aktualną chwilą i ze sobą nawzajem (...) (Gee, Green, 1998: 139).

Wyróżnione przez Gee i Green zadania, które budowane są w procesie tworzenia tekstu, zarówno ustnego, jak i pisanego, są wyrazem społecznej natury języka. W kontekście analizy procesów uczenia się pozwalają spojrzeć na nie jako na zjawisko socjokulturowe. Opisują je jako proces, w ramach którego konstruowane są poszczególne okazje do uczenia się, budowane są relacje pomiędzy poszczególnymi podmiotami interakcji, zachodzą działania, a także konstruowane są różnorodne, chwilowe, światy społeczne.

Każdy z obecnych w tym procesie czterech wyróżnionych obszarów wymagać będzie osobnego podejścia - jedne semiotycznego, inne socjokulturowego. Dlatego też Gee i Green piszą, że niezbędne dla analizy dyskursywnej tego procesu jest zrozumienie, czym jest język. Swoją koncepcję osadzają w teorii Bakhtina, mówiącej, że każdy język składa się z różnych języków społecznych (Bakhtin, 1981). Każdy z czterech wyróżnionych obszarów konstruowany jest zatem przez zasoby i struktury gramatyczne języków społecznych. W procesie komunikacji przełączamy się na różne języki społeczne, zależnie od aktualnego kontekstu. Co więcej, struktury te są hybrydyczne, ponieważ zmieniają się i płynnie w siebie przechodzą konteksty, w jakich są one używane (Gee, Green, 1998: 142). W tym kontekście analiza dyskursu to analiza języków społecznych, pojawiających się w różnych kontekstach społecznych, w tym w procesie ucze- 
nia się. Uczenie się jest tutaj rozumiane jako zbiór zmieniających się wzorów uczestnictwa w specyficznych praktykach społecznych w ramach praktykujących wspólnot (Gee, Green, 1998: 147). Wspólnoty te produkują i reprodukują siebie w ramach procesów społecznych i praktyk, w tym uczenia się. Interakcje, które zachodzą w ramach poszczególnych wspólnot instytucjonalnych oraz społecznych, równocześnie strukturyzują i są strukturyzowane przez działania zachodzące pomiędzy uczestnikami interakcji. Inaczej mówiąc, struktury te są ustanawiane w trakcie interakcji.

Gee i Green, odwołując się do prac Normana Fairclougha, przenoszą ten mechanizm na poziom dyskursu. Każde zdarzenie dyskursywne ma bowiem trzy wymiary - jest to mówiony lub pisany tekst językowy, jest to przypadek praktyki dyskursywnej, oznaczającej produkcję i interpretację tegoż tekstu oraz jest to przykład praktyki społecznej. W tej perspektywie uczenie się „podobnie jak tekst albo struktura społeczna, jest produktem zachodzących w każdym momencie i z biegiem czasu działań członków grup społecznych” (Gee, Green, 1998: 148). Tak widziane, jako praktyka dyskursywna, pozwala nam analizować modele kulturowe, praktyki społeczne, a także praktyki dyskursywne wnoszone przez poszczególnych uczestników tego procesu.

Uczenie się jako praktyka dyskursywna będzie mieć również znaczenie w perspektywie całożyciowej, proces ten związany jest bowiem $\mathrm{z}$ konstruowaniem własnych dyskursów uczenia się, zanurzonych w kulturowym i społecznym doświadczeniu jednostki. Można powiedzieć w tym kontekście o społecznych środowiskach uczenia się, czy o krajobrazach uczenia się, lub też ekologiach wiedzy, w ramach których tymczasowo wytwarzane są i stabilizowane znaczenia (Evans, Kurantowicz, 2009; Evans, 2013). Evans używa również sformułowania „przestrzeń uczenia się”. Jest ona tranzycyjna, zachodzą w niej różnorodne procesy, oraz refleksyjna, albowiem w jej ramach konstruowane jest własne „refleksyjne Ja” w relacji do znaczących Innych (Evans, 2013: 18). Pamięć, doświadczenie i związki emocjonalne, które uruchamiane będą w procesie uczenia się, odnosić będą się do całej zawodowej, osobistej i emocjonalnej biografii jednostki, a więc również do jej dotychczasowych relacji ze światem społecznym. Doświadczenie to, jak ujmuje to Evans, artykułowane może być w ramach dyskursów uczenia się, opartych na złożonych "gramatykach mówienia”, światy językowe czy też narracje zbudowane na podstawie wiedzy biograficznej (Evans, 2013: 18). Dotyczy to przede wszystkim refleksji na temat własnych procesów uczenia się, widzianych w kontekście innych doświadczeń życiowych. Z tego też powodu perspektywa ta stosowana jest w badaniach biograficznych (Evans, 2013). 


\section{Puste znaczące w dyskursie uczenia się}

Refleksja nad procesami uczenia się w perspektywie dyskursywnej każe zastanowić się, jakie symbole nadawać mogą temu procesowi znaczenie. Jest to szczególnie istotne w kontekście procesów tożsamościowych. W tej części mojego artykułu chciałabym spojrzeć na dyskursywną przestrzeń procesu uczenia się poprzez pryzmat teorii Ernesto Laclau.

Według Laclau przedmiotom i działaniom przypisywane jest znaczenie, które pojawia się w ramach systemów składających się ze znaczących różnic, czyli $\mathrm{w}$ ramach dyskursu. Pisze on, że „dyskurs jest podstawowym obszarem budowania obiektywności jako takiej. Mówiąc o dyskursie (...) nie mam na myśli czegoś, co zasadniczo ogranicza się do sfery mowy i pisma, lecz każdy zespół elementów, w którym konstytutywną rolę odgrywają relacje”" (Laclau, 2009: 63). W jego ramach mogą pojawić się wątki hegemoniczne, które wiążą w całość różne wątki dyskursu, dążąc do zdominowania pola dostępnych znaczeń, a tym samym do wytworzenia warunków do wytworzenia tożsamości przedmiotów i praktyk (Howarth, 2008: 157-159). Interesujące staje się pytanie: jakie symbole, czyli, mówiąc językiem teorii dyskursu Laclaua, puste znaczące, dominują pole dyskursu uczenia się? Skupię się na kilku najbardziej reprezentatywnych przykładach.

Dostępne analizy prowadzone przy wykorzystaniu teorii Laclau pokazują, że w obrębie dyskursu uczenia się występuje cała gama pustych znaczących, mogących go hegemonizować. To na przykład „uczenie się przez całe życie” (life-long learning) (Montessori, 2011; Jurgiel-Aleksander, Jagiełło-Rusiłowski, 2013). Stało się ono wszechobecną metaforą opisu rozwoju zarówno jednostki, jak i całych społeczeństw, obecną zarówno w dokumentach edukacyjnych państw i organizacji międzynarodowych, jak i w narracjach dotyczących rozwoju jednostki.

Nie zawsze, tak jak „społeczeństwo wiedzy” (Szkudlarek, 2007), puste znaczące muszą bezpośrednio nawiązywać do procesu uczenia się. Obecne w polu dyskursu uczenia się są takie puste znaczące jak: „partnerstwo” (Burgos, 2003), a także puste znaczące odnoszące się do wiedzy i rozumienia takie jak „,kompletny”, „częściowy” „niepoprawny”, „bez znaczenia” (Land, Rattray, Vivian, 2014).

Również samo „uczenie się" może stać się pustym znaczącym (Hansen, 2005). Hansen twierdzi, że jako pustemu znaczącemu „uczeniu się" mogą być nadawane różnorodne znaczenia $\mathrm{w}$ zależności od kontekstu, w jakim się pojawia. Według niego nie istnieje żadne „naturalne” znaczenie przypisane do uczenia się. Jest to raczej pole różnych znaczeń, kontestacji i metaforyzacji. Jego analizy kontekstu duńskiego pokazują, że puste znaczące "uczenie się" mogło być powiązane z takimi znaczonymi jak „literacki”, „kontrola dorosłych”, „nauka”, „pochodzić z zewnątrz” 
czy „głowa”. W opozycji do nich stały takie powiązania jak „zabawa”, „wolne dzieciństwo”, „rozwój”, „pochodzić z wnętrza dziecka” oraz „ciało”. Wskazywałoby to, że znaczenia nadawane uczeniu się są konstruowane społecznie oraz historycznie (Hansen, 2005: 6).

Dyskurs uczenia się może mieć też niebagatelne znaczenie dla procesów związanych z tworzeniem się struktur społecznych współczesnych społeczeństw kapitalistycznych. Tomasz Szkudlarek zwraca w tym kontekście uwagę na rolę, jaką w ekonomicznym dyskursie o edukacji odgrywają puste znaczące osadzone w dyskursie uczenia się, jak wspomniane już „społeczeństwo wiedzy” (Szkudlarek, 2007). Społeczeństwa kapitalistyczne składają się w tej optyce z różnorodnych wspólnot uczących się oraz wiedzących, posiadających jednak różny dostęp do wiedzy, czyli też materialnych i niematerialnych zasobów, posiadanie których warunkuje miejsce w strukturze społecznej.

\section{Kulturowe aspekty uczenia się i konstruowanie tożsamości}

Ostatnim z obszarów, na który chciałabym zwrócić uwagę w kontekście rozważań nad uczeniem się jako obszarem dyskursywnie konstruowanym, są kulturowe zależności ten dyskurs warunkujące. Interesującym obszarem wydają się tutaj badania nad procesem uczenia się języka obcego wśród dorosłych. W kontekście ciekawym punktem odniesienia są badania z zakresu procesów tożsamościowych oraz językoznawstwa prowadzone przez Bonny Norton.

Według Bonny Norton w procesie uczenia się języka zachodzi proces konstruowania tożsamości, które negocjowane są poprzez język. Sam język natomiast odzwierciedla struktury społeczne, nadając temu, co mówimy i w jaki sposób mówimy, określone granice (Norton, 1997: 5). Pozycja społeczna uczących się, a więc ich klasa społeczna, płeć, rasa oraz pochodzenie, będą zatem znaczące w kontekście procesu uczenia się, który formować będzie się pod wpływem rozmaitych struktur władzy.

Zakładając, że posiadanie tożsamości łączy się z pragnieniem rozpoznania, przynależności i bezpieczeństwa, Norton stwierdza, że pragnienie to nie może zostać oddzielone od społecznej dystrybucji zasobów materialnych. Dostęp do nich warunkuje bowiem rozumienie własnej relacji ze światem czy też posiadanych możliwości. Jak pisze Norton, pytanie „kim jestem?” nie może zostać oddzielone od pytania „co wolno mi zrobić?”, oba nie mogą być natomiast rozumiane w oderwaniu od struktury materialnej, na której opiera się możliwość realizacji tych pragnień (Norton, 1997: 8). To ona definiuje to, w jaki sposób pragnienia te 
będą artykułowane. Tożsamość będzie kształtować się w kierunku, jaki nadadzą jej zmieniające się relacje społeczne i ekonomiczne.

W komunikacji, co rozciągnąć też możemy na proces uczenia się, istotne będą zatem złożone sieci relacji społecznych. Istotne będzie zatem to, kto słucha, a kto jest warty, aby go słuchać, lub też, aby mówić. Odwołując się do prac Pierre’a Bourdieu, Norton stwierdza, że poszerzona definicja kompetencji komunikacyjnych powinna zawierać „prawo do mówienia” oraz „moc narzucania odbioru” (Norton, 1997: 8).

W pracach Norton pojawiają się również dwie inne interesujące z punktu widzenia badań nad procesami uczenia się kategorie. Są to: własność języka (ownership of language) oraz, zaczerpnięte $\mathrm{z}$ teorii Benedicta Andersona, wspólnoty wyobrażone.

Pytanie o własność języka jest szczególnie istotne w kontekście uczenia się języka obcego i wiąże się z pytaniem, do kogo należy język - czy jest on własnością tych, którzy mówią w nim od urodzenia, czy też również uczących się? W konsekwencji zapytać należy, kto ma legitymację do posługiwania się językiem. Bonny Norton zadaje te pytania w kontekście tożsamości uczących się języka, zwłaszcza migrantów (Norton, 1997).

Wspólnoty wyobrażone uczących się to pojęcie odnoszące się do związków pomiędzy uczeniem się, a rzeczywistością społeczną, a dokładniej, wyobrażeniami, jakie mamy na temat rzeczywistości społecznej. Wyobrażenia te dotyczą również naszej przynależności do określonej grupy społecznej, a co się z tym wiąże, wyobrażeń na temat tego, jakie umiejętności, kwalifikacje, czy też język jest dla tej wspólnoty pożądany (Pavlenko, Norton, 2007). Dotyczą zatem określonej, również dyskursywnej, konstrukcji świata społecznego.

Patrząc na uczenie się jako przestrzeń dyskursywnie konstruowaną w świetle analiz Bonny Norton, warto zwrócić uwagę na jej kulturowe uwarunkowania. Pozwala ona, na przykład w kontekście różnorodności społecznej, postawić pytanie o to, co i przez kogo artykułowane jest w ramach procesu uczenia się. Uzmysławia też, że proces uczenia się nie zachodzi tak samo dla wszystkich aktorów społecznych. Badania samej Bonny Norton nad migrantkami w Kanadzie pokazują, jak pochodzenie narodowe oraz klasa społeczna różnicują ten proces. To, czego badane uczyły się na kursach językowych migrantki, dając określone narzędzia opisu rzeczywistości, pozycjonowało je w ramach określonej struktury społecznej (Norton, 1997a). Jeśli proces uczenia się rozumieć będziemy w kontekście emancypacji, takie pytanie o dyskursywne procesy uczenia się pociąga za sobą pytanie o możliwą sprawczość podmiotu uczenia się w ramach tego dyskursu, a także edukacji, w ramach której możliwe jest artykułowanie podmiotowych znaczeń. 


\section{Podsumowanie}

Niniejszy artykuł jest przyczynkiem do rozważań na temat dyskursywnego wymiaru procesu uczenia się. Szczegółowe ujęcie, jak w przypadku wszelkich prac z zakresu krytycznej analizy dyskursu, wymaga wglądu empirycznego, dającego możliwość prześledzenia dynamiki tego dyskursu. Teoretyczna rekonstrukcja głównych wątków dotyczących uczenia się jako przestrzeni dyskursywnej pozwala jednak zarysować obszary, w ramach których zachodzić będą procesy konstruowania tożsamości indywidualnych oraz zbiorowych.

Istnieją dwie główne metafory obrazujące uczenie się - metafora zdobywania, która oznacza, że uczenie to zdobywanie jakiegoś rodzaju towaru, oraz metafora partycypacji, w której uczenie się jest konceptualizowane jako wspólnota praktyki i zmieniających się ról oraz tożsamości (Sfard, 1998: 6). Wydaje się, że osadzone $\mathrm{w}$ teorii dyskursu koncepcje uczenia się upominają się o to drugie rozumienie, ujmując uczenie się jako przestrzeń społecznie kreowaną, w której zachodzi ścieranie się sił społecznych, ale możliwa jest również realizacja własnej sprawczości. Pytanie o dyskursywną naturę procesu uczenia się jest zatem również pytaniem o inkluzywność i ekskluzywność zachodzące w ramach tego procesu, a także pytaniem o możliwość upodmiotowienia oraz emancypacji uczących się. Pod tym względem dyskursywnym koncepcjom blisko do tradycji pedagogiki krytycznej $\mathrm{z}$ jej tradycją upominania się o głos wykluczonych w procesach edukacyjnych.

\section{Literatura}

Bakhtin M. (1981). The Dialogic Imagination. Austin.

Biesta G.J.J. (2010). Good Education in an Age of Measurement. Ethics, Politics, Democracy. London.

Burgos R.B. (2003). Partnership as a floating and empty signifier within educational policies: the Mexican case. [W:] M.B. Franklin, M. Bloch, T. Popkewitz (eds.). Educational Partnerships and the State: The paradoxes of Governing Schools, Children, and Families. Basingstoke, s. 55-79.

Evans R. (2013). Learning and knowing. Narratives, memory and biographical knowledge in interview interaction. „European Journal for Research on the Education and Learning of Adults” 4(1), s. $17-31$.

Evans R., Kurantowicz E. (2009). Learning in changing educational landscapes: migration at the margins and biographical narratives of identity in transition. „Between Global and Local”, s. 65-78.

Field J. (2000). Lifelong Learning and the New Educational Order. London.

Gee J.P., Green J. (1998). Discourse analysis learning and social practice: a methodological study. „Review of Research in Education” 23, s. 119-169.

Hansen A.D. (2005). Politics and metaphor - a discourse theoretical analysis, Paper to be presented at ECPR conference. 
Hicks D. (1996). Contextual inquiries: A discourse-oriented study of classroom learning. [W:] D. Hicks (ed.). Discourse, Learning, and Schooling. New York.

Howarth D. (2008). Dyskurs. Warszawa.

Jurgiel-Aleksander A. (2013). Doświadczenie edukacyjne w perspektywie andragogicznej. Studium biograficzno-andragogiczne. Gdańsk.

Jurgiel-Aleksander A., Jagiełło-Rusiłowski A. (2014). Dyskurs uczenia się przez całe życie: administrowanie kompetencjami czy pytanie o ich sens i znaczenie? „Rocznik Andragogiczny” 20, s. 65-74.

Koschmann T. (1999). Toward a dialogic theory of learning: Bakhtin's contribution to understanding learning in settings of collaboration. [W:] C. Hoadley, J. Roschelle (eds.) „Proceedings of the 1999 conference on Computer support for collaborative learning. International Society of the Learning Sciences, Palo Alto, California. Mahwah, NJ.

Laclau E. (2009). Rozum populistyczny. Wrocław.

Land R., Rattray J., Vivian P. (2014). Learning in the liminal space: A semiotic approach to threshold concepts. „Higher Education” 67(2), s. 199-217.

Menard-Warwick J. (2005). Transgression narratives, dialogic vocing, and cultural change. „Journal of Sociolinguistics" 9(4), s. 534-557.

Mercer N. (2004). Sociocultural discourse analysis. „Journal of Applied Linguistics” 1(2), s. 137-168.

Mignolo W. (2002) The geopolitics of knowledge and the colonial difference. „The South Atlantic Quarterly" 101(1), s. 57-96.

Montessori N.M. (2011). The design of a theoretical, methodological, analytical framework to analyse hegemony in discourse. „Critical Discourse Studies” 8(3), s. 169-181.

Norton B. (1997). Language, identity, and the Ownership of English. „TESOL Quarterly” s. 409-429.

Norton B. (2000). Identity and Language Learning: Gender, Ethnicity and Educational. Change.

Pavlenko A., Norton B. (2007). Imagined communities, identity, and English language learning. „International Handbook of English Language Teaching", s. 669-680.

Sfard A. (1998). On two metaphors for learning and the dangers of choosing just one. „Educational Researcher" 27(2), s. 4-13.

Szkudlarek T. (2007) Empty signifiers, education and politics. „Studies in Philosophy and Education” 26(3), s. 237-252.

Wickman P.O., Östman L. (2002). Learning as discourse change: A sociocultural mechanism. „Science Education" 86(5), s. 601-623.

Young R. (1990). White Mythologies. Writing History and the West. London-New York. 